\title{
O mito da Democracia
}

\author{
Luís Felipe Junqueira de Andrade
}

STELLE, José. O Estado de Direito: Constitucionalismo, democracia e o futuro da nação. São Paulo: Chiado Books, 2019. 226p.

Em 1958, Ludwig von Mises foi convidado para ministrar uma série de palestras na Argentina. $\mathrm{Na}$ época, o mundo vivenciava a batalha entre dois sistemas econômicos diametralmente opostos: o Capitalismo e o Socialismo.

Mises, intransigente quando se tratava de defender as ideias da liberdade, fora ousado em atacar o comunismo e o socialismo, pois até então a fraude da prosperidade soviética ainda não havia sido escancarada. Essas palestras, posteriormente, foram transformadas em um dos mais conhecidos livros do economista austríaco: As Seis Lições (1959).

José Stelle, PhD em Filosofia Política e fundador do Instituto Liberal do Rio de Janeiro, com um vasto conhecimento do constitucionalismo americano e das ideias da Escola Austríaca (em particular, das ideias de Friedrich von Hayek) - quem teve a oportunidade de conhecer pessoalmente no início da década de 1980 -, apresenta-nos uma obra que pode ser facilmente nomeada como As outras seis lições.

Se Mises fora ousado ao contestar o comunismo e o socialismo, Stelle ousa ao contestar a democracia, termo que há muito perdeu seu sentido original, e hoje é usado para designar os mais elevados predicados, ora se confunde com liberdade, ora se confunde com justo, ora se confunde com integridade, tudo a depender do interlocutor e do grau de proselitismo e demagogia.

Com efeito, na obra O Estado de Direito, José Stelle resgata o sentido original de democracia como governo da maioria, sendo apenas um método de ação política baseado na contagem de votos, que, todavia, não leva automaticamente à liberdade e à igualdade, sequer representando a sociedade como um todo.

DOI https://doi.org/10.30800/mises.2019.v7.1173

* Advogado, Especialista em Direito Empresarial - FGV. E-mail: 1fjandrade@hotmail.com 
Conforme reitera o advogado e filósofo italiano, Bruno Leoni, fortemente influenciado por Mises e Hayek, a representação da sociedade encontra os seguintes problemas:

1. como fazer com que o número de cidadãos autorizados a escolher representantes correspondesse à real estrutura da nação; 2 . como arranjar candidatos que se dispusessem à função de representantes e que fossem expoentes adequados da vontade das pessoas representadas; e 3. como adotar um sistema de escolhas de representantes que resultasse em um reflexo adequado das opiniões das pessoas representadas. (LEONI, 2010, p. 125)

Nesse sentido, na Palestra Quatro: Crítica à Constituição, destaco o seguinte trecho do economista austríaco Joseph Schumpeter, citado por Stelle: “o método democrático é um sistema institucional para a tomada de decisões políticas, em que [alguns] indivíduos adquirem o poder de decidir mediante uma luta competitiva pelos votos do eleitor" (SCHUMPETER, 1961 apud STELLE, 2019, p. 68).

Porém, é inevitável que tal método termine com grupos organizados usando o voto do povo, de maneira demagógica, para perpetuação no poder e constante aumento do Estado. Há, assim, uma verdadeira captura do método democrático.

Além de demonstrar os perigos da democracia absoluta, as palestras de José Stelle apresentam uma crítica fundamentada à Constituição Americana, analisando as principais inconsistências no principal documento jurídico-político dos Estados Unidos.

Nesse ponto, importante salientar o alerta feito pelo autor com respeito à capacidade de $\mathrm{o}$ processo democrático distorcer a Constituição, tendendo a gerar um legislativo com poderes absolutos.

Para Stelle, as maiores inconsistências da Constituição Americana, potencializada pelo processo democrático, residem nos poderes do Congresso, o qual o autor chama de imprudente por aumentar o limite de sua própria dívida e tomar empréstimos, aliados à fraude monetária do FED em emitir moeda e emprestá-la ao governo.

Em resumo, a destruição do Estado de Direito pelo método democrático está no poder do Estado em aumentar dívida, tomar empréstimos, cunhar moeda, determinar seu valor e inflacionar.

Por fim, Stelle, fazendo subsunção ao sistema político proposto por Hayek, a demarquia, propõe algumas reflexões a fim de evitarmos as inconsistências verificadas na Constituição Americana, por meio da tríade Constitucionalismo, Representação e Estado de Direito.

Como direção para uma reforma constitucional, ele aponta uma espécie de Regime Constitucional Liberal, fundamentado em leis gerais, abstratas e universalmente aplicáveis, que mitigam os efeitos nefastos do método democrático e impedem a tirania legislativa. Afinal, quem gasta o orçamento não pode estabelecer impostos: há um claro conflito de interesses.

Na presente obra, creio que José Stelle une-se a Antony Mueller e Hans Hermann Hoppe nas consistentes críticas à democracia e ao Estado, se afastando desses dois apenas quanto à crença na possibilidade de reformar este Estado, torná-lo moral, íntegro e neutro, por meio de uma drástica redução do método democrático, extinção de partidos políticos e de uma lei universalmente aplicável. 
Concluo, para encerrar, que a obra o Estado de Direito: constitucionalismo, democracia e o futuro da nação é certamente um contraponto ao mainstream acadêmico, ao mito envolto no termo democracia. Stelle trata o conceito com sobriedade, sem sentimentalismo irreal, evidenciando as verdadeiras consequências desse método político ao longo da história, especialmente nos Estados Unidos da América, nação que aparentemente abandonou a defesa da liberdade pela defesa da democracia. Um erro que pode ser fatal.

Enfim, a distância entre a democracia e o socialismo é uma eleição.

\section{Referências}

LEONI, Bruno. Liberdade e a Lei. São Paulo: Instituto Ludwig von Mises, 2010.

MISES, Ludvig von. As seis lições. Auburn: Mises Institute, 1959.

RECEBIDO EM: 15/03/2019

APROVADO EM: 30/03/2019 